\title{
Physa acuta Draparnaud, 1805 (Gastropoda: Physidae): a Study of Topotypic Specimens
}

\author{
W Lobato Paraense/ ${ }^{+}$, Jean-Pierre Pointier*
}

\begin{abstract}
Departamento de Malacologia, Instituto Oswaldo Cruz-Fiocruz, Av. Brasil 4365, 21045-900 Rio de Janeiro, RJ, Brasil
*Laboratoire de Biologie Marine et Malacologie, EPHE, UMR 5555 du CNRS, Université de Perpignan, Perpignan, France

A description is given of Physa acuta Draparnaud, 1805, based on topotypic specimens from the Garonne river basin, and additional samples from the environs of the French cities of Montpellier and Perpignan. It proved indistinguishable, in shell and anatomy, from topotypic Physa cubensis Pfeiffer, 1839, thus leading the authors to admit the synonymy of the two nominal species under the older name, P. acuta.
\end{abstract}

Key words: Physa acuta - Physa cubensis - synonymy

This species was described by Draparnaud (1805 : 55, Pl. III, Figs. 10, 11) as follows:

\section{P. aiguë. P. acuta.}

P. testâ sinistrosâ ovatâ; spirâ brevissimâ acutâ; peristomate marginato.

Desc. L'animal n'a point de digitations au manteau.

Coquille assez semblable à la précédente [Physa fontinalis], mais plus grande, plus ventrue, plus épaisse, moins transparente, moins luisante, de couleur un peu cendrée, striée longitudinalement. Quelquefois même les stries forment des bandes pâles longitudinales sur le dernier tour qui est trèsgrand. La base de la columelle est profondément sinuée avec un bord blanc. Ouverture grande et rétrécie supérieurement; péristome bordé en dedans d'un bourrelet blanc. La spire a cinq tours et est aiguë à son sommet.

Habite dans la Garonne et les rivières qui s'y jettent.

\section{MATERIALS AND METHODS}

The snails were collected from four places in the Garonne basin: Saint Léger (on Garonne river), Viale (on Baïse river), Clairac (on Lot river), tank at Saint Étienne de Fougères. Additional samples were collected from an artificial pond at Montpellier and a canal at Perpignan.

The specimens to be dissected were relaxed for $8 \mathrm{~h}$ in a $0.05 \%$ solution of nembutal. Then they were immersed for $40 \mathrm{sec}$ in water heated at $70^{\circ} \mathrm{C}$, from which they were transferred to water at room temperature. The animals (under water) were drawn from the shell with a small forceps applied to the cephalopedal mass, and fixed in slightly modified Railliet-Henry's fluid (distilled water $930 \mathrm{ml}$, sodium chloride $6 \mathrm{~g}$, formalin $50 \mathrm{ml}$, glacial acetic acid $20 \mathrm{ml}$ ).

Voucher specimens were deposited in the Museum National d'Histoire Naturelle de Paris (Laboratoire de Biologie des Invertébrés Marins), the École Pratique des

${ }^{+}$Corresponding author. Fax: $+55-21-2280.5840$. E-mail: paraense@ioc.fiocruz.br

Received 11 December 2002

Accepted 19 March 203
Hautes Études of Perpignan (Laboratoire de Biologie Marine et Malacologie), and the Malacological Collection of Instituto Oswaldo Cruz.

\section{DESCRIPTION}

Shell (Fig. 1) elongate-ovate, thin, smooth, moderately lustrous and translucent, light fawn colored; fine, closeset lines of growth, non-perceptible spiral lines. Protoconch distinct, rounded exserted. Whorls 5, regularly and rapidly increasing, the first minute, the last very large, roundly shouldered. Spire short. Suture slightly impressed. Aperture large, ear-shaped, about $3 / 4$ total length of shell; outer lip thin, sharp; inner lip closely appressed to the columellar region completely closing the umbilical region; columellar plait somewhat twisted; parietal callus wide, columellar fold well marked. Largest shell $16 \mathrm{~mm}$ in length, $9 \mathrm{~mm}$ in width.

Cephalopedal mass uniformly dark gray. Fig. 2 shows some features of a crawling specimen: labial palps fanlike, slightly bilobed anteriorly, roundly angled laterally; foot tapering to a pointed caudal tip that does not overreach the shell apex. Roof of pulmonary cavity deeply pigmented and flecked with small circular to oval unpigmented spots. Renal tube (Fig. 3, rt), as usual in physids, tightly folded into a zig-zag course, ending by a short ureter which opens through a subterminal meatus just behind the pneumostome. Mantle collar (Fig. 3, mc) with about 3-5 digitations on the apical (ad) and 5-10 on the columellar (cd) region, reflected - the latter more extendedly - over the edge of the shell. By the way, in the original description of $P$. acuta it is stated that "the animal has no mantle digitations at all", whereas seven digitations over the columella are mentioned by Moquin-Tandon (1855).

Reproductive system (Fig. 4) - Ovotestis (ot) embedded in the digestive gland. Ovotestis follicles (about 80 in a minutely dissected specimen) emptying into a collecting canal which continues into the ovispermiduct. Between the proximal $\left(\mathrm{od}_{1}\right)$ and distal $\left(\mathrm{od}_{2}\right)$ segments of the latter are the seminal vesicles (sv). The ovispermiduct empties into the carrefour, as well as the albumen gland (removed in the figured specimen).

From the carrefour the oviduct (ov) emerges as a narrow tube which runs leftwards, gradually widens, becomes 
bosselated and highly convoluted, proceeding into the nidamental gland (ng). This latter shows no remarkable features and narrows to the uterus (ut) and vagina (va), which receives the spermathecal duct (sd), about twice as long as the spermatheca (sp).

Immediately after emerging from the carrefour the spermiduct gives off a series of short prostatic diverticula (pr). They are closely packed, so that their numbers are difficult to determine; in one thoroughly dissected specimen about 45 units were recorded. They may be simple or divided into usually 2-4 short branches. After giving off the last diverticulum the spermiduct continues into the vas deferens (vd), which opens into the caudal end of the penis. The penis sheath (ps) is somewhat swollen proximally, tapering gradually distalward and expanding into a sarcobellum at its junction with the prepuce. The penis, free within the penis sheath (ps), decreases in width toward its extremity, and has a terminal outlet (Fig. 4, pe). The prepuce (pp), much wider than the penis sheath, is from about as long to twice as long as the latter; a lenticular gland (pg) is present on the proximal half of the preputial wall. A set of retractor $(\mathrm{rpc})$ and protractor $(\mathrm{pm})$ muscles are inserted into the walls of the penial complex.

Some radular teeth are shown in Fig. 5.

\section{DISCUSSION}

Many records have been published of $P$. acuta ouside its type locality, and only in a few of them was its identification based on anatomic characters: Moquin-Tandon (1855), from France, Slugocka (1913), from Switzerland, and Aboul-Ela and Beddiny (1969), from Egypt. The following citations, although not exhaustive, give an idea of its ubiquity:

In Europe: Austria (Strouhal 1934); Belgium (Adam 1960); Bulgaria (Dragneva \& Kanev 1983); Czechoslovakia (Wohlgemuth 1987); England (Cooper 1918); Germany
(Martens 1902); Greece (Eleutheriades et al. 1993); Hungary (Soós 1917); Italy (Clessin 1886); Malta (Mienis 1987); Netherlands (Meeuse \& Hubert 1949); Northern Ireland (Dillon et al. 2002); Poland (Feliksiat 1939); Portugal (Azevedo et al. 1967); Romania (Iordau et al. 1964); Russia (Kazannikov 1978); Scotland (Jenkins 1890); Sicily (Sowerby 1873-74); Spain (Clessin 1886); Ukraine (Stadnishenko 1972); Yugoslavia (Krkac 1982);

In Asia: Azerbaijan (Aliev 1960); Bangladesh (Begum \& Nazneens 1992); China (Dudgeon \& Lam 1985); Georgia (Kurashvili et al. 1986); India (Raut et al. 1995); Iran (Massoud \& Hedayeti-Far 1979); Iraq (Altaif et al. 1978); Israel (Mienis 1983); Japan (Gotoh \& Kawata 2000); Jordan (Burch et al. 1989); Korea (Ha et al. 1981); Malaysia (Ali 1993); Oman (Brown \& Gallagher 1985); Pakistan (Nazneen et al. 1992); Saudi Arabia (Magzoule \& Kasim 1980); Tadzhikistan (Izzatullajev 1978); Turkestan (Lindholm 1929);

In Africa: Algeria (Bourguignat 1864); Botswana, Ethiopia (Brown 1965); Kenya, Mauritius, Rhodesia, Transvaal (Mandahl-Barth, after Verdcourt 1971); Madagascar (Brygoo 1968); Mauritania, Reunion, Zimbabwe (Madsen \& Frandsen 1989); Morocco (Mohamed \& Najat 1998); Namibia (Brown et al. 1985); Nigeria (Fashuyi 1990); South Africa and Uganda (Bruggen 1966); Sudan (Brown et al. 1984); Tunisia (Pallary 1923); Zaire (Mandahl-Barth et al. 1974);

In Australia and Hawaii: Burch and Tottenham (1980); In North America: USA (Beetle 1973 in Virginia), Clench (1934 in Massachusetts).

Such ubiquity was expressed by Smith (1989), who also discusses the methods of dispersal and colonization of non-marine molluscs: "Two of the six species considered ecologically insignificant are found in every region of the world. These are the snail Physella acuta (Draparnaud) and the minute bivalve Pisidium

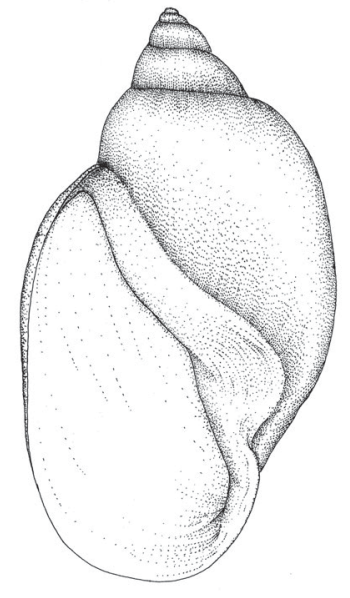

1

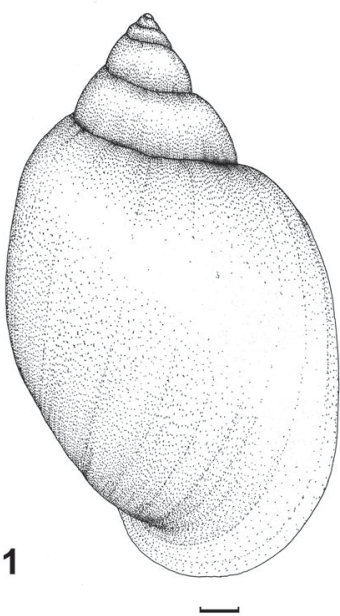

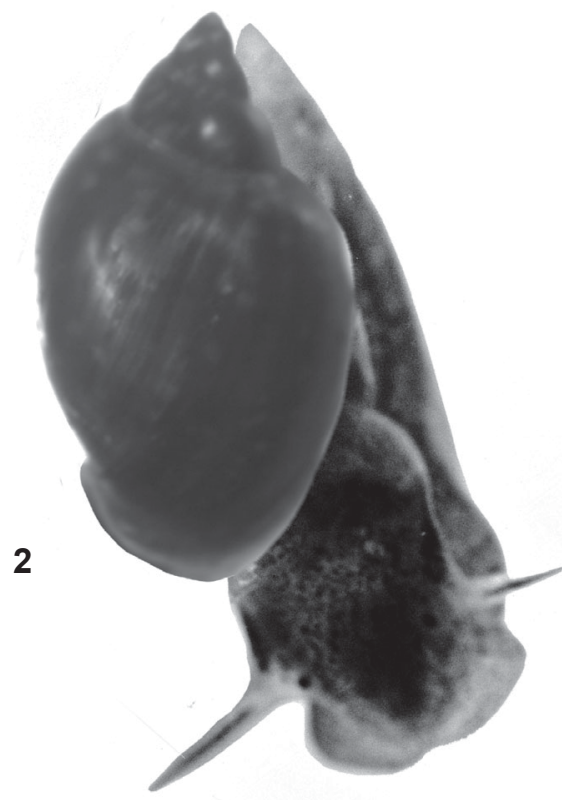

Physa acuta. Fig. 1: shell. Fig. 2: crawling specimen. Bar $=1 \mathrm{~mm}$ 


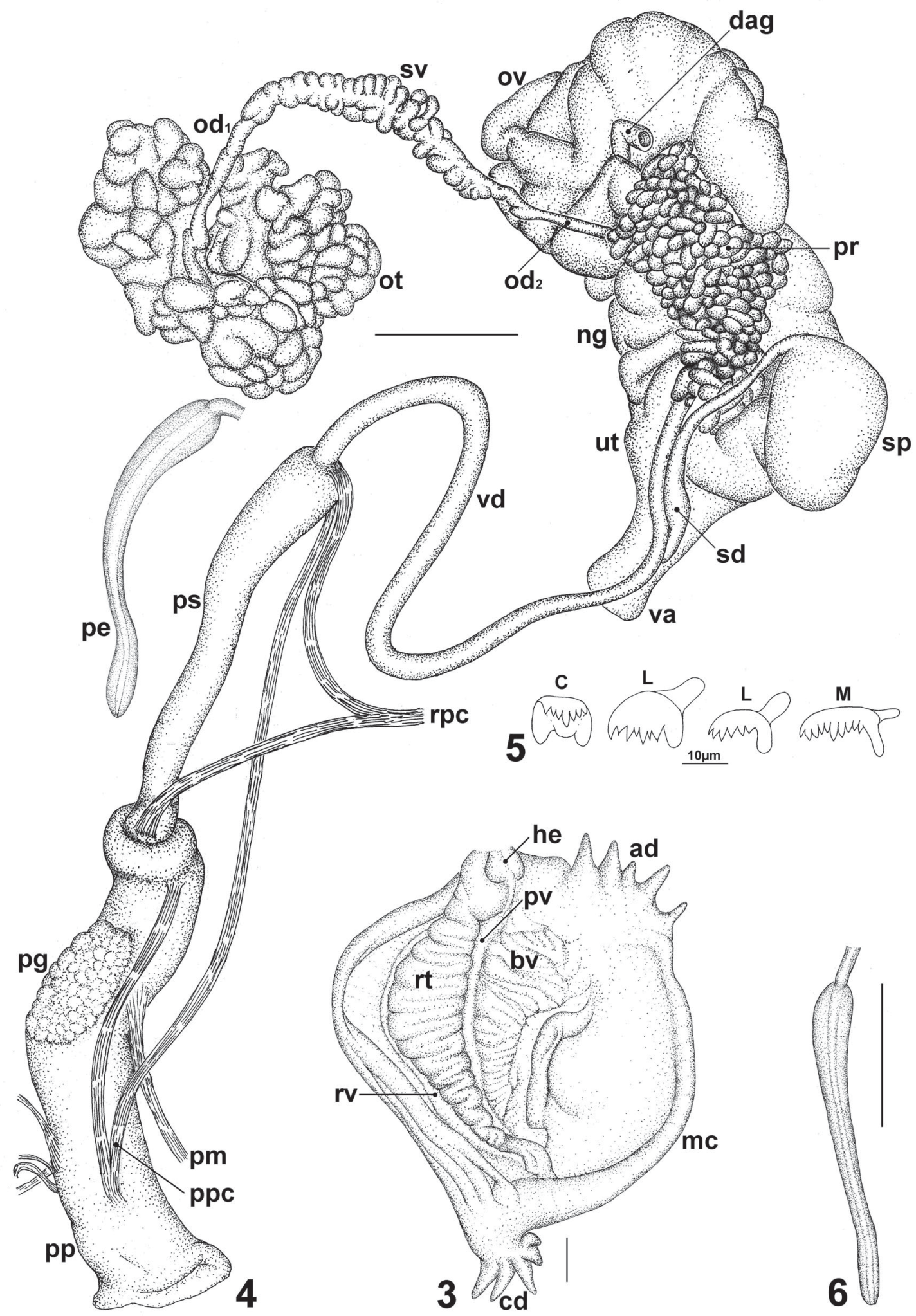

Physa acuta. Fig. 3: roof of pulmonary cavity $(\mathrm{ad}=$ apical digitations of mantle collar; bv $=$ blood vessels; cd $=$ columellar digitations of mantle collar; he $=$ heart; $\mathrm{mc}=$ mantle collar; $\mathrm{pv}=$ pulmonary vein; $\mathrm{rt}=$ renal tube; $\mathrm{rv}=$ renal vein). Fig. 4: reproductive system $(\mathrm{dag}=\mathrm{duct}$ of albumen gland - gland removed; $\mathrm{ng}=$ nidamental gland; $\mathrm{od}_{1}=$ proximal segment of ovispermiduct; $\mathrm{od}_{2}=$ distal segment of ovispermiduct; ot = ovotestis; ov - oviduct; $\mathrm{pe}=$ penis; $\mathrm{pg}=$ preputial gland; $\mathrm{pm}=$ protractor muscle of prepuce; $\mathrm{pp}=$ prepuce; ppc $=$ protractor muscle of penial complex; $\mathrm{pr}=$ prostate; $\mathrm{ps}=$ penis sheath; $\mathrm{rpc}=$ retractor muscles of penial complex; $\mathrm{sd}=$ spermathecal duct; $\mathrm{sp}=\mathrm{spermatheca}$; $\mathrm{sv}=$ seminal vesicles; ut $=$ uterus; va $=$ vagina; $\mathrm{vd}=$ vas deferens $)$. Fig. 5 : radular teeth $(\mathrm{C}=$ central; $\mathrm{L}=$ lateral; $\mathrm{M}=$ marginal $)$. Fig. 6 : penis of "Physa cubensis" from Batabanó, Cuba. Bar (unless otherwise stated) $=1 \mathrm{~mm}$ 
casertaneum Poli, both of which may have spread with only limited assistance from man".

The likeness in shell characters of $P$. acuta to $P$. cubensis is mentioned by Pfeiffer (1839) in his description of the latter: "Sehr ähnlich unsrer europäischen $P h$. acuta Dr." Such similarity is also observed in the anatomic characters (see Paraense 1987), pointing to the synonymy of the two nominal species under the older name, Physa acuta. By the way, in Paraense's (1987) paper it was erroneously stated that "the penis has an axial canal with a subterminal outlet"; as seen in Fig. 5 of that paper and Fig. 6 of the present one, the outlet is really terminal.

\section{ACKNOWLEDGEMENT} tion.

To the technologist JE Prado for the graphic documenta-

\section{REFERENCES}

Aboul-Ela IA, Beddiny EAM 1969. Anatomical and functional studies on the reproductive system of Physa acuta Draparnaud, 1805. Proc Zoolog Soc Un Arab Rep 3: 131162.

Adam W 1960. Faune de Belgique. Mollusques I. Mollusques Terrestres et Dulcicoles, Inst Roy Sci Nat Belg, Belg, Brussels, $402 \mathrm{pp}$.

Ali JH 1993. The distribution of Physa acuta Draparnaud (Gastropoda: Physidae) in Malaysia and its suitability as test material for insecticide toxicity studies. JMed Appl Malacol 5: $129-134$.

Aliev AD 1960. On the molluscan fauna of Lower Kura. Izvest Akad Nauk Azerb SSR 5: 115-118.

Altaif KI, Al-Abbassy SN, Al-Saqur IM, Jawad AK 1978. Experimental studies on the suitability of aquatic snails as intermediate hosts for Paramphistomum cervi in Iraq. Ann Trop Med Parasitol 72: 151-155.

Azevedo JF, Barreira F, Gil FB, Gomes FAC 1967. Calcium absorption by Australorbis glabratus and Physa acuta in constant concentration environment. Rev Inst Med Trop São Paulo 9: 419-428.

Beetle DE 1973. Physa acuta in Virginia. Nautilus 87: 28.

Begum F, Nazneen S 1992. Systematic study of molluscan fauna of Layari River, part 5: Basommatophora (Pulmonata). Bangladesh J Zool 20: 135-141.

Bourguignat JR 1864. Malacologie de l'Algérie, ou Histoire Naturelle des Animaux Mollusques Terrestres et Fluviatiles Recueillis jusqu'à ce Jour dans nos Possessions du Nord de l'Afrique. $4^{\mathrm{e}}$ fascicule, Paris.

Brown CJ, Macdonald IAW, Brown SE 1985. Invasive alien organisms in South West Africa/Namibia. South Afr Natl Sci Programs 119: 1-74.

Brown DS 1965. Freshwater gastropod Mollusca from Ethiopia. Bull Brit Mus Nat Hist Zool 12: 37-94.

Brown DS, Gallagher MD 1985. Freshwater snails of Oman, South Eastern Arabia. Hydrobiol 127: 125-149.

Brown DS, Fison T, Southgate VR, Wright CA 1984. Aquatic snails of the Jonglei region, southern Sudan, and transmission of trematode parasites. Hydrobiol 110: 247-271.

Bruggen AC van 1966. Physa acuta, an introduced species new to South Africa. J Conchol 26: 49-50.

Brygoo ER 1968.Les bilharzioses humaines à Madagascar. In Santé et Développement, Premier Congr Intern Sci Méd Madagascar, 1-165.

Burch JB, Tottenham JL 1980. North American freshwater snails. IV. Species list, ranges and illustrations. Walkerana 1: 81-215.
Burch JB, Bruce JI, Amr Z 1989. Schistosomiasis and malacology in Jordan. J Med Appl Malacol 1: 139-163.

Clench WJ 1934. Physa acuta Draparnaud in Massachusetts. Nautilus 48: 33.

Clessin S 1886. Die Familie der Limnaeiden, etc. Bauer \& Raspe, Nürnberg.

Cooper JE 1918. Physa acuta Drap. in Middlesex. J Conchol 15: 233

Dillon RT Jr, Wethington AR, Rhett JM, Smith TP 2002. Populations of the European freshwater pulmonate Physa acuta are not reproductively isolated from the American Physa heterostropha or Physa integra. Invertebr Biol 121: 226234.

Dragneva N, Kanev I 1983. Antigen similarity between rediae and cercariae of Echinoparyphium aconiatum Dietz, 1909 (Trematoda: Echinostomatidae) and their intermediate hosts. Khelmintol 16: 29-36 [In Bulgarian with Russian and English summaries].

Draparnaud JPR 1805. Histoire Naturelle des Mollusques Terrestres et Fluviatiles de la France, D Colas, Paris.

Dudgeon D, Lam PKS 1985. The effects of feeding and starvation on the foraging strategies of three freshwater pulmonate species. In B Morton, D Dudgeon (eds), The Malacofauna of Hong Kong and Southern China, 2. Proceedings of the second international workshop on the malacofauna of Hong Kong and southern China, Hong Kong Univ Press, Hong Kong, 681 pp.

Eleutheriades N, Hatziioannou M, Lazaridou-Dimitriadou M 1993. Contribution to the study of the biology of Bithynia graeca (Prosobranchia Gastropoda) and Physa acuta (Pulmonata Gastropoda) in Lake Kernini (north Greece). Buil Gallo-Hellenica 20: 267-272.

Fashuyi SA 1990. Freshwater gastropod molluscs in Ondo State, Nigeria. J Afr Zool 104: 165-170.

Feliksiak S 1939. Physa acuta Drap. in den Fabrikteichen von Lodz und ihre allgemeine Verbreitung. Fragm Faun Mus Zool Polon 4: 243-258.

Gotoh T, Kawata M 2000. The effects of spatial habitat structure on population variability of freshwater snails. Hydrobiol 429: 157-169.

Ha YC, Hong SW, Kim HS, Chung YH, Won PO, Ha YK, Lee K, Choi HK, Ahn TS 1981. Review of the Ecology of the Han River, Institute of Science, Seoul Nat Univ, Seoul, p. 224-225.

Iordau P, Ciobanu A, Dumitrescu M, Dulipovici N 1964. The gastropod fauna of the pastures of a collective farm near Giurgiu. Lucr Stünt Inst Agron 7c: 307-315 [In Rumanian with English summary]

Izzatullajev ZI 1978. Fauna of land and freshwater mollusks in the newly developed lands of the Javan Valley of Tadzhikistan and some regularities of its formation. Malacol Rev 11: 80.

Jenkins AJ 1890. Physa acuta (Drp.) in Scotland. J Conchol 6: 270-271.

Kazannikov EA 1978. Contents and zoogeographical analysis of the freshwater malacofauna of the Terek drainage. Malacol Rev 11: 86-87.

Krkac N 1982. Effect of sudden temperature change on behaviour, oviposition and mortality in Physa acuta Draparnaud (Gastropoda, Pulmonata). Malacologia 22: 167-170.

Kurashvili BE, Kanev I, Matsaberidze GV, Chumburidze RS 1986. On species affinity of echinostomes with 37 spines on the collar in conditions of Georgia. Soobshchenyia Akad Nauk Gruz SSR 123: 633-635 [In Russian with English and Georgian summaries]. 
Lindholm W 1929. Drei interessante Wasserschneken (Gastropoda) aus dem westlichen Turkestan. $C R$ Acad Sci Leningrad: $311-314$.

Madsen H, Frandsen F 1989. The spread of freshwater snails including those of medical and veterinary importance. Acta Trop 46: 139-146.

Magzoule M, Kasim AA 1980. Schistosomiasis in Saudi Arabia. Ann Trop Med Parasitol 74: 511-513.

Mandahl-Barth G, Ripert C, Raccurt C 1974. Nature du soussol, répartition des mollusques dulcaquicoles et foyers de bilharzioses intestinale et urinaire au Bas-Zaire. Rev Zool Afr 88: 553-584.

Martens E 1902. Eine für die Provinz Brandenburg neue Süsswasserschnecke, Physa acuta Drap. S B Ges Naturf Fr Berl: 166-168.

Massoud J, Hedayeti-Far M 1979. Freshwater mollusk fauna of the Khuzestan and Khorram-abad areas in southwestern Iran. Malacol Rev 12: 96.

Meeuse ADJ, Hubert B 1949. The mollusc fauna of glasshouses in the Netherlands. Basteria 13: 1-30.

Mienis HK 1983. A preliminary checklist of the freshwater molluscs of Israel and the administered areas. Levantina 47: $543-550$

Mienis HK 1987. A note concerning Physa from Malta. Levantina 69: 719-722.

Mohamed F, Najat M 1998.Co-occurrence de Physa acuta Draparnaud et vecteurs intermédiaires de la bilharziose au Maroc. 1 - Dephasage des cycles biologiques de P. acuta Draparnaud et Planorbarius metidjensis Forbes. Riv Idrobiol 37: 169-177 [1999].

Moquin-Tandon A 1855. Histoire Naturelle des Mollusques Terrestres et Fluviatiles de France, Vol. 2, JB Baillière, Paris, 646 pp.
Nazneen S, Begum F, Erum N, Jahan N 1992. Study of jaws and radula of some fresh water gastropods in relation to their feeding habits. Proc Pakistan Congr Zool 12: 589598.

Pallary P 1923. Faune malacologique des eaux douces de la Tunisie. Arch Inst Pasteur Afr Nord 12: 22-47.

Paraense L 1987. Physa cubensis Pfeiffer, 1839 (Pulmonata: Physidae). Mem Inst Oswaldo Cruz 82: 15-20.

Pfeiffer L 1839. Bericht über die Erbegnisse meiner Reise nach Cuba im Winter 1838-1839. Arch Naturgesch 5: 346-358.

Raut SK, Bhaumik S, Das S 1995. Occurrence of the snail Physa acuta Draparnaud in Calcutta, India. J Bombay Nat Hist Soc 92: 434.

Slugocka M 1913. Recherches sur l'appareil génital des Gastéropodes pulmonés du genre Physa. Rev Suisse Zool 21: 75-109.

Smith BJ 1989. Travelling snails. J Med Appl Malacol 1: 195 204.

Soós L 1917. Vizsgálatok a magyarországi pulmonáták rendszertani anatomiája köréböl. Ann Mus Nat Hung 15: 1165 [In Magyar, German summary].

Sowerby GB Jr 1873-74. Monograph of the genus Physa. In Reeve: Conchologia Iconica 19 (313,319), 26 pp., 12 pl, Reeve, Benham \& Reeve, London.

Stadnichenko AP 1972. Review of fauna and ecology of Gastropoda from the western regions of the Ukraine. Vestnik Zool 6: 68-72 [In Russian, English summary].

Strouhal H 1934. Biologische Untersuchungen an den Thermen von Warmbad Villach in Kärnten. Arch Hydrobiol 26: 495583.

Verdcourt B 1971. Physa in East Africa. J Conchol 26: 417.

Wohlgemuth E 1987. The occurrence of the bladder snail Physa acuta in Brno. Ziva 35: 65 [In Czech]. 